ситуативной обусловленности (компоненты и градации) / К. Менг // Психолингвистика: сб. статей / [отв. ред. А. М. Шахнарович]. - М., 1984. - С. 241-259. 11. Монтессори М. Помоги мне сделать это самому / Мария Монтессори; [сост., вступ. статья М. В. Богуславский, Г. Б. Корнеулов]. - М. : ИД «Карапуз», 2002. - 272 с. 12. Пироженко Т. А. Коммуникативно-речевое развитие ребенка / Пироженко Т. А. - К. : Норе-принт, 2002. - 309 с. 13. Федоренко Л. П. Методика развития речи детей дошкольного возраста: [пособ. для уч-ся дошк. пед. училищ] / Лидия Прокофьевна Федоренко. - М. : Просвещение, 1977. - 239 с.

УДК 796.01

H. I. Аииток, доктор філософських наук, доиент, Дрогобииький державний педагогічний університет імені Івана Франка

\title{
ФОРМУВАННЯ МОВЛЕННЯ ДІТЕЙ ДОШКІЛЬНОГО ВІКУ 3 ОСОБЛИВИМИ ПОТРЕБАМИ В КОНТЕКСТІ ГУМАНІСТИЧНОЇ ПАРАДИГМИ
}

Ашиток Н. И. Формування мовлення дітей дошкільного віку з особливими потребами у контексті гуманістичної парадигми

Стаття присвячена вивченню стану сформованості творчого зв'язного мовлення у дошкільників iз затримкою психічного розвитку та визначенню ефективних методів $\mathrm{i}$ прийомів, які забезпечують формування та розвиток комунікативно-мовленнєвих умінь зазначеної категорії дітей.

Ключові слова: діти з затримкою психічного розвитку, мовленнєва діяльність, творче зв'язне мовлення, дошкільні установи.

Ашиток Н. И. Формирование речи детей дошкольного возраста с особенными потребностями в контексте гуманистической парадигмы.

Статья посвящена изучению состояния сформированности творческой связной речи у дошкольников с задержкой психического развития и выделению эффективных методов и приемов, которые обеспечивают формирование и развитие коммуникативно-речевых умений этой категории детей.

Ключевые слова: дети с задержкой психического развития, речевая деятельность, творческая связная речь, дошкольные заведения.

Ashytok N. I. Forming speech at the preschooler with special needs through the prism of humanistic paradigm of education.

The article deals with the problem of studying the state of organizing creative coherent speech at the preschooler with delay of mental development and determination of effective methods and tools which provide for forming and development communicative knowledge of definite category of children.

Key words: child with the delay of method development, language activity, creative coherent speech, abstract thoughts, imagination, school establishments.

Гуманістична парадигма освіти в Україні покликана орієнтувати навчально-виховний процес на становлення всебічно і гармонійно розвиненої особистості, здатної вирішувати проблеми сьогодення й майбутнього. Згідно з Національною доктриною розвитку освіти у XXI столітті вдосконалення освітньої системи передбачає максимальне врахування особистісних та психофізичних особливостей дітей та створення для них належних умов для навчання i розвитку. У цьому контексті актуальною проблемою української педагогічної теорії і практики $є$ реалізація прав особливих дітей дошкільного віку 3 порушеннями в мовному розвитку. Дослідження проблем комунікативно-мовленнєвого розвитку згаданих осіб зумовлюється необхідністю своєчасно сформувати в них базові здатності до засвоєння знань у процесі взаємодії і взаєморозуміння між неповнолітніми та іншими людьми, до інтеріоризації дошкільниками етичних норм міжособистісної взаємодії.

Існує значний досвід дослідження дитячого мовлення в лінгвістичному плані: засвоєння норм словника, граматики, фонетики, інтонаційної виразності (Н. Гавриш, 
А. Горєлова, М. Когут, Н. Пахомова, Т. Пироженко, В. Шкльода та ін.) [2; 3; 4, с. 15-17; 6, с. $1-5 ; \quad 9$, с. $48-50 ; 11 ; 12$, с. $281-293 ; 13$, с. $1-12]$. Особливості мовленнєвокомунікативного розвитку дошкільників з особливими потребами також були предметом вивчення [1; 8; 9]. У цій статті пропонується розглянути проблеми формування комунікативно-мовленнєвих навичок у цієї категорії дітей у контексті гуманістичної освітньої парадигми, деякі принципи якої визначено у Базовому компоненті дошкільної освіти у нашій державі. Цими принципами є зорієнтованість на особистість, формування в неї свідомого, ціннісного ставлення до навколишньої дійсності, забезпечення умов для духовного зростання дитини. Водночас для втілення в життя зазначеної парадигми педагогам-практикам необхідно мати чітке й повне уявлення про внутрішній світ дітей, щоб оцінити змістові складові дитячої картини світу та визначити найбільш ефективні засоби збагачення світобачення, забезпечення виховного впливу на дошкільників 3 особливими потребами. Саме тому вивчення цих складників, засобів їх формування та усунення порушень у процесі становлення особливих дітей актуалізуються. Метою cmammi є дослідження одного із напрямів роботи із зазначеною категорією дітей подолання мовленнєвих недоліків, що ускладнюють їхній розвиток, у контексті гуманістичної парадигми.

В останні десятиріччя у вітчизняній та зарубіжній психолого-педагогічній літературі обговорюється проблема зміни освітньої парадигми [7]. Існуючу когнітивно-орієнтовану парадигму освіти передбачається змінити на гуманістичну особистісно зорієнтовану. Головним аргументом прибічників упровадження особистісно орієнтованої освіти вважається те, що завданням традиційної когнітивно-орієнтованої освіти є формування знань, умінь та навичок, а розвиток та виховання у іï контексті $\epsilon$ «другорядним продуктом». Аналізуючи динаміку історичного розвитку ідей виховання в освіті, вітчизняний дослідник І. Д. Бех [7] визначає існування двох виховних стратегій, двох етапів розвитку педагогічної науки. Перший - етап соціоцентризму, коли педагогічна діяльність зосереджується в основному на соціальному розвитку особистості - члена певної групи, спільноти, суспільства. Другий - етап людиноцентризму, базовою основою якого є ідеї гуманізму, взаємодії як співчуття, співтворчості. Гуманістична ідея, що передбачає сходження людини до вищих духовно-моральних цінностей, є основою гуманістичної парадигми, якій притаманні такі переваги: вільний вибір школи або альтернативного навчального закладу батьками й дітьми; призначення керівників освіти на підставі їхніх особистісних якостей та професійних знань; актуалізація у контексті економічних реформ потреб на нові спеціальності та спеціалізації, які передбачають особистісну спрямованість [7].

Перша 3 цих переваг передбачає вибір навчальних закладів батьками і неповнолітніми навіть у тому випадку, коли йдеться про дітей з особливими потребами. Звісно, такі заклади необхідно адаптувати до можливостей цих школярів, сприяючи їхній інклюзії включенню до колективу повносправних дітей, а у майбутньому до суспільства.

Інклюзивна освіта в країні підтримана законодавчо. Конституція України, Закон України «Про освіту» гарантують особливим дітям право на освіту, а отже, і можливість реалізувати це право в державних навчальних закладах незалежно від статі, раси, національності, соціального та майнового стану, стану здоров'я, місця проживання та інших обставин. Ці неповнолітні мають право задовольнити свої потреби так само, як й інші члени суспільства. Нині особи з певними відхиленнями в розвитку здобувають освіту в спеціальних навчальних закладах або закладах комбінованого типу - спеціальних садках (групах), школах-інтернатах. Поступово впроваджується ще одна інноваційна модель навчання - інклюзивна, яка забезпечує для особливих дітей доступ до якісної освіти шляхом їх зарахування в масову школу (клас), дитячий садок (групу). Визнано, що діти в таких умовах краще адаптуються до навколишнього середовища, оволодівають соціальними навичками, відчувають себе самостійними і потрібними суспільству. 
У Канаді, США та інших державах накопичено досвід щодо залучення дітей 3 особливими потребами до навчання в загальноосвітніх закладах за місцем проживання [10http://www.logopediya.com.ua/the-news/101-2011-05-15-18-55-26]. Не залишається осторонь і Україна. Із 2001 року в країні запроваджується програма Всеукраїнського експерименту «Соціальна адаптація та інтеграція в суспільство дітей, які потребують корекції фізичного та (або) розумового розвитку, шляхом запровадження інклюзивного навчання», яка реалізується на базі 22 навчальних закладів зі статусом експериментальних [5]. Розпочато роботу над упровадженням інклюзивного навчання i в дошкільних навчальних закладах, що в межах зазначеної програми і проекту Всеукраїнського фонду «Крок за кроком» за наказом Міністерства освіти і науки України 32001 року здійснюється, наприклад, у навчально-виховному комплексі «Барвінок» Голосіївського району м. Києва. У цьому закладі проводився науково-практичний експеримент «Соціальна адаптація та інтеграція в суспільство дітей з особливостями психофізичного розвитку шляхом організації їх навчання в загальноосвітніх навчальних закладах» [10]. До масових класів та груп залучалися особи з мовленнєвими порушеннями, вадами слуху, зору, затримкою психічного розвитку. Діти ставали частинкою життя педагогічного колективу. До них ставились, як до рівних і сприймали їх такими, якими вони є. Для здійснення корекційної допомоги в освітньому закладі створювалися необхідні умови. Згідно з сучасними вимогами був обладнаний логопедичний кабінет, адже своєчасне логопедичне втручання $є$ одним із важливих превентивних заходів, спрямованих на попередження труднощів у навчанні, i водночас $\epsilon$ ефективним способом стимуляції психічного розвитку дитини. Учителем-логопедом, вихователями, вчителями використовувалися різні методи і форми корекційного навчання, що передбачали кооперативну роботу дітей у малих групах та парах задля формування соціальних навичок, почуття товариськості та взаємної відповідальності [10]. Ефективними були спільні форми роботи педагогічних працівників - бінарні уроки, бінарні заняття вчителялогопеда 3 вихователем чи вчителем початкових класів, вчителя-логопеда 3 психологом, соціальним працівником, вчителя-логопеда 3 музичним керівником, на яких одночасно реалізовувались корекційні, навчальні та виховні завдання. До цих форм роботи залучалисяь батьки як активні учасники навчально-корекційного процесу. Мовленнєводіяльнісна спрямованість корекційної роботи здійснювалася через ігротерапію, арт-терапію. Проводилась індивідуальна робота - окремо з кожним із дітей, а також групова - 3 невеликими групами малюків у формі тематичних занять, вправ, ігор, інсценівок, свят, етюдів тощо [10].

У наш час робота 3 особливими неповнолітніми задля їі вдосконалення проводиться згідно із наказом МОНМС від 24.12.2010 № 1285, у якому йдеться про створення робочої групи для розроблення програм розвитку дітей дошкільного віку, які потребують корекції фізичного та (або) розумового розвитку [5]. До роботи з цією категорією дітей, окрім педагогів і логопедів, пропонується у навчальних закладах залучати асистентів учителів. Класифікатор професій 3 ініціативи Міністерства освіти і науки, молоді та спорту i Міністерства соціальної політики доповнено посадою асистента вчителя інклюзивного навчання (наказ Держспоживстандарту від 28.07.2010 р. № 327). Цю посаду передбачено також Типовими штатними нормативами загальноосвітніх навчальних закладів, затвердженими наказом Міністерства освіти i науки від 06.12.2010 p. № 1205, зареєстрованим у Міністерстві юстиції 22 грудня 2010 р. за № 1308/18603 [5].

Слід відзначити, що корекційно-розвивальна інклюзивна робота особливо успішна у період дошкільного дитинства, коли закладається основа становлення особистості. Неоціненне значення в цьому віці має корекція мовленнєвих порушень, що сприяє процесу набуття дітьми дошкільного віку мовленнєвої компетенції, необхідної для навчання у школі. Базовий компонент дошкільної освіти передбачає цю компетенцію, що виявляється в умінні адекватно й доречно, практично користуватися рідною мовою в конкретних ситуаціях (висловлювати свої думки, наміри, прохання тощо), 
використовувати для цього як вербальні, так і невербальні (міміка, жести, рухи) та інтонаційні засоби виразності мовлення [1].

Починаючи роботу з усунення мовленнєвих порушень 3 дітьми дошкільного віку 3 особливими потребами, слід передусім діагностувати причини цих порушень. Батьки здебільшого звертаються до лікаря або психолога вже тоді, коли в їхніх дітей виникають проблеми, пов'язані зі шкільною неуспішністю і дезадаптацією. Проте, діагностику i виявлення дітей «групи ризику» слід здійснювати раніше - ще під час виникнення труднощів у цих дітей під час засвоєння навчально-виховних програм у дитячих садках. А це може відбуватися в зв'язку з уповільненням темпів розвитку органів мовлення, несвоєчасністю зміни фаз ігрової діяльності, підвищеною емоційною i руховою збудливістю. Порушення мовлення можуть також зумовлюватися затримкою психічного розвитку (ЗПР), яка при відповідній корекції може бути усунена. Ознаками ЗПР є: 1) недостатність тонкої моторики рук; порушення артикуляційної і графо-моторної координації (порушення каліграфії); 2) зорово-просторові порушення: нестійкість графічного образу цифр і букв, дзеркальність і перестановки їх при читанні і написанні; труднощі орієнтації в межах аркуша зошита листа; 3) порушення звуко-буквеного аналізу та звукової структури слів, 4) труднощі засвоєння логіко-граматичних конструкцій мови, обмеженість словникового запасу; 5) порушення зорової, слухової, слухо-мовленнєвої пам'яті; 6) труднощі концентрації та розподілу уваги, фрагментарність сприйняття. Діти із затримкою психічного розвитку - це категорія дітей 3 органічними й функціональними порушеннями нервово-психічних процесів, що зумовлюють уповільненість темпу розвитку психіки дитини, що виявляється в недостатності загального запасу знань, нестійкості уваги, поверховості сприймання, ослабленій пам'яті, незрілості мислення, швидкій втомлюваності під час пізнавальної діяльності. Мовлення дітей із затримкою психічного розвитку має свої особливості і багато в чому нагадує мовлення дітей 3 нормальним розвитком, проте значно молодших. Відмінність мовлення особливих дітей виявляється у бідності словникового запасу, неузгодженості слів у реченні, відсутності диференціації окремих звуків, неправильній їх вимові. Для дітей із ЗПР на відміну від олігофренів характерна не тотальність, а мозаїчність порушень мозкових функцій, тобто недостатність одних функцій при збереженні інших, невідповідність потенційних пізнавальних здібностей і реальних досягнень [8]. Ефективними видами корекційної допомоги цим неповнолітнім $\epsilon$ актуалізація мотиву комунікативної дії, створення емоційних ігрових ситуацій; організація уваги і посилення мовного контролю, зменшення обсягу і темпу роботи, а також довготривалі види допомоги - формування довільних форм комунікативної діяльності, тренінг функціонально незрілих і ослаблених функцій (тонкої моторики, зорово-просторового та слухового сприйняття, слухо-мовленнєвої пам'яті, слухо-рухової та зорово-рухової координації тощо) [8].

Недостатня сформованість граматичної будови мовлення дітей із затримкою психічного розвитку репрезентується аграматизмами та неправильною послідовністю слів. Малюки не вживають прислів 'їв, яскравих образних висловлювань, епітетів, метафор та фразеологічних зворотів. Труднощі у них виникають у застосування узагальнюючих понять (меблі, посуд, овочі тощо). Більшість дітей із ЗПР не усвідомлюють взаємовідношення між родовими і видовими поняттями (стіл, шафа, меблі, ліжко). В експресивному мовленні ними використовується невелика кількість прикметників i прислівників [1]. Мовлення дітей із ЗПР багато в чому залежить від наявності емоційного компонента. Так, під час складання оповідання за серією сюжетних картинок, цікавих i доступних, неповнолітні можуть скласти граматично правильне складне речення, використовувати пряму мову та вносити в оповідання власні фантазії. Водночас мовлення супроводжується виразною інтонацією, адекватною мімікою й емоційними жестами. Проте, все це відбуватиметься лише тоді, коли завдання буде легким, цікавим, необмеженим часом і правилами. Під час виконання завдань із визначеними межами, коли потрібні обдумування, чітке формулювання, правильне словесне оформлення, 
спостерігається зниження мовленнєвої активності, виникають труднощі в доборі слів та неточне їх застосування. Зв'язне мовлення дітей дошкільного віку із ЗПР низького рівня розвитку: спостерігаються недостатність мовленнєвого оформлення, порушення логічного зв’язку, непослідовність у переказі. Якщо діти емоційно піднесені, вони можуть охоче долучатися до процесу спілкування і бути при цьому активними, проте свої відповіді вони не обдумують, що зумовлює у їхньому мовленні наявність зайвих асоціацій та недоречної імпульсивності [1].

Під час усунення недоліків у мовленні особливих дітей необхідно брати до уваги, що важливим компонентом становлення особистості дошкільника $є$ формування картини світу - системи світобачення, сукупності уявлень, смислових відношень, - яка виражається передусім мовними засобами в різних видах та формах дитячої словотворчості, діалогах, запитаннях, філософствуванні. Мовленнєві недоліки у дітей 3 ЗПР часто свідчать про необхідність роботи, спрямованої на становлення або корекцію цієї картини у свідомості неповнолітніх. Рівень сформованості картини світу в осіб із ЗПР повинен бути таким самим, як й у повносправних неповнолітніх. Коротко схарактеризуємо стан мовленнєвого розвитку дітей старшого дошкільного віку, що дає змогу оцінити можливості дошкільників зі звичайним рівнем розвитку застосовувати мовлення як засіб відображення картину світу. Як доводять дослідження психологів та педагогів, старший дошкільний вік характеризується значними здобутками та новоутвореннями в оволодінні мовленням й у психічному розвитку дитини загалом (Н. Астахова, Л. Виготський, Т. Пироженко та ін.). Мовлення стає не лише засобом спілкування та мислення, а й предметом свідомого вивчення, адже під час підготовки до школи у свідомості неповнолітніх закладаються основи для опанування навичок читання та письма. Розвивається звукова сторона мовлення, що виявляється в майже чистій звуковимові, здатності диференціювати звуки, розуміти та свідомо добирати засоби інтонаційної виразності. Швидко зростає словниковий запас (дитина шестирічного віку знає приблизно 5000 слів), який ускладнюється та урізноманітнюється. У ньому представлені майже всі частини мови. Діти в цьому віці знайомляться з явищем полісемії, починають опановувати синонімічні та антонімічні відношення та усвідомлювати не лише прямі, а й переносні значення слів та словосполучень (Л. Березовська, Н. Горбунова, К. Крутій, Г. Лаврентьєва, Г. Смага, Є. Струніна, В. Харченко та ін.). Дошкільники засвоюють граматичні форми мовлення, здатні контролювати правильність не лише чужого, а й власного мовлення (А. Арушанова, А. Богуш, К. Крутій, Г. Ніколайчук). Здійснюється перехід до контекстного мовлення, з'являються розгорнуті повідомленнямонологи, творчі розповіді. Діти стають здатними адекватно сприймати та передавати іншим не лише нові знання, а й репрезентувати мовними засобами власні роздуми, переживання, почуття (Л. Калмикова, Н. Харченко, Л. Порядченко, Т. Постоян та ін.) [2]. Застосуються складні мовні конструкції та відбувається перехід до розгорнутих висловлювань, що зумовлено виникненням нових завдань спілкування, які з'являються в дітей у цьому віці. Малюки намагаються розібратися з усім, із чим стикаються, знайти відповіді на всі запитання і повідомити оточенню про осягнуте ними.

$\mathrm{y}$ дітей із затримкою психічного розвитку за допомогою педагогічних працівників формується картина світу максимально така ж, як і в повносправних дошкільників. Фактично, основним завданням при роботі 3 неповнолітніми 3 затримкою психічного розвитку $\epsilon$ передусім не виправлення недоліків у їхньому мовленні, а становлення відповідної для цього віку картини світу, яка виражається мовними засобами. Піклуючись про усунення мовленнєвих порушень в осіб дошкільного віку, педагоги створюють передумови удосконалення картини світу в їхній свідомості. Подоланню мовленнєвих порушень сприяє комунікативне середовище, яке й намагаються створити в закладах інклюзивної освіти, адже це забезпечує можливість особливим дітям здобувати знання спільно зі «здоровими» школярами в одному класі.

Для гуманістичної освітньої парадигми в Україні характерний пріоритет особистісного 
розвитку дитини. Альтернативною формою здобуття знань, соціального досвіду, життєвої компетенції дітьми з особливими потребами є інклюзивна освіта. Підготовку цих дітей до навчання в загальноосвітніх школах потрібно здійснювати заздалегідь - у дошкільних закладах, які потребують реорганізації, зокрема, зарахування до педагогічно-виховного складу логопедів та асистентів вихователів. Важливим напрямом цієї підготовки є робота 3 формування картини світу у свідомості неповнолітніх i усунення порушень у застосуванні мовних засобів - репрезентантів цієї картини.

\title{
Література
}

1. Використання невербальних засобів комунікації у корекційній роботі з дітьми старшого дошкільного віку із ЗПР. - [Електронний ресурс]. - Режим доступу: http://www.logopediya.com.ua/the-news/284-2012-02-19-20-23-17. 2. Гавриш Н. Відбиття в мовленні дошкільників особливостей світорозуміння. - [Електронний ресурс]. - Режим доступу: http://ukrdeti.com/2010/2_a4_2010.html 3. Гавриш Н. Розвиток мовленнєво-творчої діяльності в дошкільному дитинстві : [монографія] / Н. Гавриш. - Донецьк : Лебідь, 2001. - 238 с. 4. Горєлова А. Формуємо зв'язне мовлення / А. Горєлова // Дошкільне виховання. - 2004. - № 4. - С.15-17. 5. Інформація відділу інклюзивного навчання та інтернатних закладів про запровадження інклюзивного навчання - [Електронний ресурс]. - Режим доступу : http://mon.gov.ua/index.php/ua/diyalnist/osvita/doshkilna-ta-zagalna-serednya/osvita-osib-z-osoblivimi-

potrebami 6. Когут М. В. Принципи розвитку мовлення та навчання дітей дошкільного віку рідної мови / М. В. Когут // Мовленнєва веселка. - 2006. - № 1-2. - С.1-5. 7. Майбутній вчительвихователь: пріоритети гуманістичної парадигми. - [Електронний ресурс]. - Режим доступу: http:// izmix.org.ua/stat.php?id=11 8. Особливості пізнавальної діяльності дітей із затримкою психічного розвитку. - [Електронний ресурс]. - Режим доступу: http://ua-referat.com 9. Пахомова Н. Мовленнєва готовність дітей дошкільного віку з тяжкими вадами мовлення / Н. Пахомова // Дефектологія. - 2005. - № 3. - С. 48-50. 10. Перші кроки до інклюзивного навчання. - [Електронний ресурс]. - Режим доступу: Ошибка! Недопустимый объект гиперссылки. the-news/101-2011-0515-18-55-26. 11. Пироженко Т. А. Мовленнєве зростання дошкільника / Т. А. Пироженко // Науковометодичний посібник. - К. : Грайлик, 1999. - 40 с. 12. Пироженко Т. А. Мовленнєвий розвиток дитини дошкільного віку / Т. А. Пироженко // Актуальні проблеми сучасної української психології: Наукові записки Інституту психології ім. Г.С. Костюка АПН України / за ред. академіка С. Д. Максименка. - К. : Нора-Друк, 2003. - Вип.23. - С.281-293. 13. Шкльода В. М. Розвиваємо мовлення дошкільників / В. М. Шкльода // Мовленнєва веселка. - 2003. - № 17-18. - С.1-12.

УДК 378.147:78+372 (07)

\author{
О. А. Бєлікова, \\ асистент, \\ Криворізький педагогічний інститут \\ ДВНЗ «Криворізький начіональний університет»
}

\section{ПІДГОТОВКА ВИХОВАТЕЛІВ ДО РОЗВИТКУ ОСОБИСТОСТІ ДОШКІЛЬНИКА ЗАСОБАМИ МУЗИЧНОГО МИСТЕЦТВА}

Бєлікова О. А. Підготовка вихователів до розвитку особистості дошкільника засобами музичного мистецтва.

У статті висвітлено змістовий компонент професійної підготовки майбутніх фахівців дошкільної освіти з урахуванням його модернізації. Звертаючись до музичного мистецтва через популяризацію серед вихователів методів та прийомів музикотерапії, приклади яких надаються в статті, окреслено їх вплив на розвиток особистості дошкільника.

Ключові слова: професійна підготовка вихователя, музичне мистецтво, музикотерапія.

Беликова О.А. Подготовка воспитателей к развитию личности дошкольника средствами музыкального исскуства.

В статье раскрыт содержательный компонент профессиональной подготовки будущих специалистов дошкольного образования с учетом его модернизации. Обращаясь к музыкальному искусству посредством популяризации среди воспитателей методов и приёмов музыкотерапии, 